\title{
Development of Mathematics Lesson Equipment Based On M-APOS Model to Improve Creative Thinking Skill on Grade X Students at Senior High School
}

\author{
$1^{\text {st }}$ Shelvia Mandasari \\ Department of Mathematics, \\ Universitas Negeri Padang \\ Padang, Indonesia \\ mandasari_shelvia@yahoo.co.id
}

\author{
$2^{\text {nd }}$ I Made Arnawa \\ Department of Mathematics, \\ Universitas Negeri Padang \\ Padang, Indonesia \\ arnawa1963@gmail.com
}

\author{
$3^{\text {rd }}$ Atmazaki \\ Department of Mathematics, \\ Universitas Negeri Padang \\ Padang, Indonesia \\ atmazaki2002@yahoo.com
}

\begin{abstract}
Lesson plan and student worksheet were an important component in the process of learning. The MAPOS model was one of the learning model which can trigger students to construct their own knowledge and able to connect all of the knowledge with the subject before. This research is developmental research by using Ploomp model. The purpose of this study is to know the characteristics of lesson plan and student worksheet based on M-APOS model. The results showed that lesson plan and student worksheet based on M-APOS model has fulfilled the validity.
\end{abstract}

\section{Keywords: $M-A P O S$, lesson equipment, creative thinking, plomp model}

\section{INTRODUCTION}

Mathematics plays an important role in various disciplines. National Research Council In Shadiq said "Mathematics is also the key to opportunities". Therefore, it is not surprisingly that mathematics is one part of science that must be mastered by learners ranging from basic education to college. In this era of reform, everyone must be able to compete because of the ever changing challenges of the future as well as the increasingly high competition so that one is required to have Four Cs (4C) skills of creativity, critical thinking, communication, and collaboration. No exception in the process of learning mathematics for one of the goals of learning mathematics in the Regulation of Department of Education and Culture (Permendikbud) Number 64 of 2013 at the school level is that students have the ability to think critically, logically and creatively. This implies that the ability to think creatively is one of the important abilities possessed by a learner.

However, in fact the ability of creative thinking of learners in Indonesia has not been optimal. This fact is based on the results of a study conducted by the International Trends International Mathematics and Science Study (TIMSS) organized by the International Association for the
Evaluation of Educational Achievement (IEA) in 2011 in mathematical ability that sees three aspects of the cognitive domain of knowledge, application and reasoning. The average of the correct answer of Indonesian learners compared to the international average on reasoning ability is only 17\% (Happy and Widjajanti, 2014:2) or 2.30\% lower than the ability of the application and $6.59 \%$ lower than the ability of knowledge. This indicates the weakness of creative thinking ability of Indonesian students. This is because the reasoning according to Krulik and Rudnick (in Happy and Widjajanti, 2014) includes basic thinking, critical thinking and creative thinking. Based on the results of Pisa in 2015, Indonesia ranked 69 out of 76 participating countries, where the ability assessed is the ability to solve problems, reasoning ability and communication skills.

The low ability and achievement that the learners still have in mathematics learning is an indicatior that the learning objectives have not been achieved optimally. Based on the observations of several high schools in the city of Payakumbuh namely SMA N 2 Payakumbuh and SMA N 3 Payakumbuh, we found that students have not smoothly poured their ideas on the problems given, students have not been able to construct their own knowledge, memories and understanding of the previous material is still lacking, participants students are still fixated on what is exemplified by teachers and learners have not been able to finish everything in a way that is diverse and unique. This indicates the lack of creative thinking ability of learners.

Based on the results of interviews with teachers, information was obtained that learners have a little difficulty in solving mathematical problems given because the lack of mastery of learners of the previous material. In addition, learners have not smoothly poured their ideas in the learning process. This is seen through learners who still often ask the teacher about completion done by learners. Learners have not been able to do everything in a way that is different from 
the one that has been exemplified before. Learners are still fixated on what previous teachers have taught.

When making observation, students are given several questions to see how their creative thinking skills, one of the question as below :

$$
\begin{aligned}
& \text { "Look at the system: } \\
& \begin{array}{l}
x+3 y+\frac{1}{2} z=\frac{1}{a}+\frac{1}{b} \\
-x-8 y-2 z=\frac{2}{b}-\frac{1}{c}
\end{array} \\
& 2 x-y-\frac{5}{4} z=\frac{1}{a}-\frac{1}{c}
\end{aligned}
$$

If the conclusion of the system is $(3,-1,4)$, find the value of $(a+b+c)$ ! Describe your answer by completely!"

One of the answers given by students as seen in Figure 1:

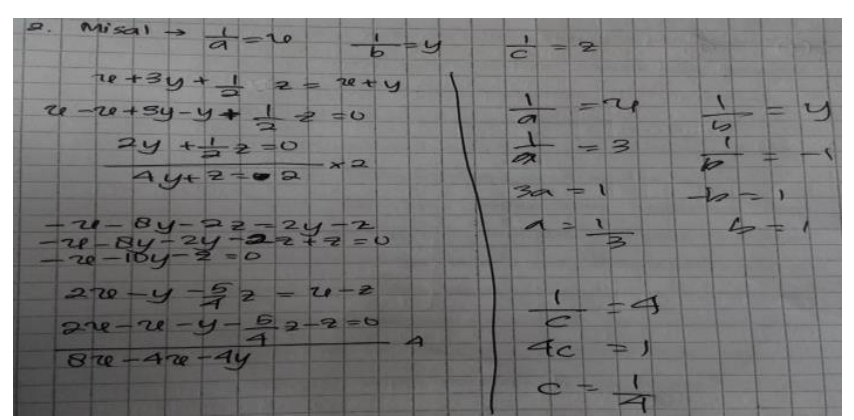

Figure 1. One f the Answers Given by Students

Learning APOS model is one of the learning models that enable learners to construct their own knowledge, encourage early knowledge, solve structured mathematical problems, repeat it and evaluate work independently. APOS is an acronym for action, process, object and schema. The APOS theory is basically a model to illustrate how mathematical concepts can be studied. The theory is a framework used to explain how individuals mentally build mathematical concepts. Asiala (1997:3) said that the characteristics of learning model of APOS is learning using (1) knowledge constructed by learners through mental construction of APOS, (2) using computer, (3) learners study in small group, and (4) using ACE cycle.

However, the APOS model has a particular obstacle to computer usage. In the learning process, it is quite difficult to apply because of several factors. One of them is the lack of teachers' and learners' skills of the programs in the computer, especially mathematics programs. In addition, the preparation of programming language is quite difficult for programs that have been made to run properly. This is reinforced by the results of research conducted by Nurlaelah (2009) which reveals the application of APOS learning model using a computer by utilizing ISETL to find constraints such as in the preparation of instructions. For example that there is a little mistype causes the expected program is not running so that students cannot understand and draw conclusions from the program.

Based on this case, it can be concluded that APOS model is difficult to be implemented so that in this study, a modification has been made. The activity on computer are replaced by Working Student Worksheet but the mental construction still follows the mental construction of the APOS model. The learning cycle in this model includes activities in doing student worksheet, class discussions and doing the exercises. This model of learning is here in after called the M-APOS learning model.

In order for the learning process to run properly should be supported by the availability of learning tools. The availability of adequate learning tools will help teachers in implementing the learning process so that objectives and learning goals which is expected can be achieved optimally. Syllabus is one of the curriculum development products that contains the outline of learning materials, learning activities and assessment design. Complete, detailed and systematic presentation steps are outlined in the form of a Lesson Plan. Learning activities in lesson plan are prepared by prioritizing the learning process in an interactive, inspirational, fun, motivating learners to be active and creative during learning so that learners are able to develop their mindset. The lesson plan also serves as a facilitator for learning enhancement that facilitates the interaction of learners such as asking, expressing opinions and understanding knowledge and procedures learned.

However, lesson plan used by teachers has not been designed optimally in developing the mindset of learners. Based on the analysis of lesson plan used by teachers in SMA Negeri in Payakumbuh, it is seen that lesson plan has not optimally involve students actively in engineering and initiating learning activities and construct their own knowledge so that learners give less attention to learning. In addition, the learning steps contained in the lesson plan only in the form of outlines only. One of the lesson plan used in SMA N 3 Payakumbuh as figure 2:

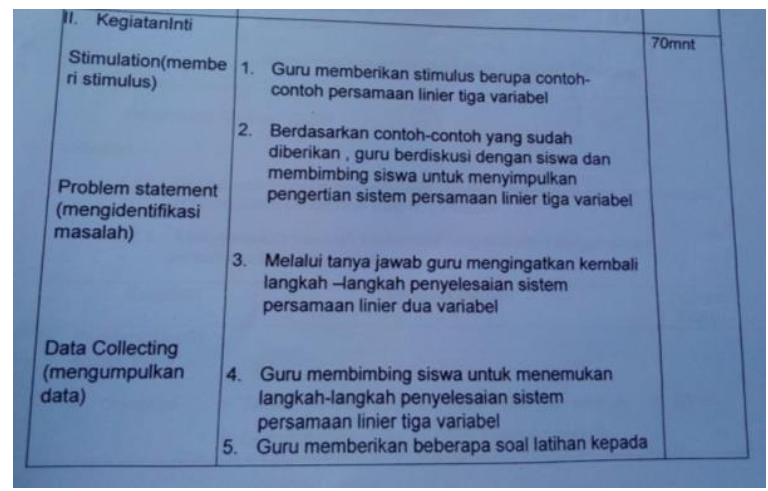

Figure 2. Example of Presentation of Main Activities in Lesson Plan

Based on the picture 1, it can be seen that learning model used is Problem Based Learning. However, the lesson steps in the main activities of the lesson plan have not 
described detailed. Descriptions of learning activities described only in the form of outlines and no explanation. For example, in the stage of stimulation is not explained what kind of stimulus given to the learner and the absence of the example intended in the description of the activity, so that learners are able to deduce the meaning of the system of linear equations of three variables.

In addition to the availability of lesson plan, in the lesson also needed a guide for learners to understand the acquisition of information for the material taught that is student worksheet. Student worksheet are sheets that contain clues, clear instructions so that learners understand the concepts being taught. However, the availability of student worksheet is still very minimal and not yet effective. The existing student worksheet is not the student worksheet which is designed solely by the teacher according to the subject and the learning objectives but the student worksheet which is issued by several publishers to the school. Based on the analysis on student worksheet offered, the authors see the material presented in student worksheet very succinct so that learners do not find the process to find the concept. Learners are given facts and information without being given the opportunity to construct their own math ideas. Through the presentation of the material in the form of a summary, the unavailability of opportunities for learners to think about the material in more depth. Besides that, in student worksheet mostly contain multiple choice questions rather than questions and descriptions. One of the student worksheet used in schools as in figure 3.

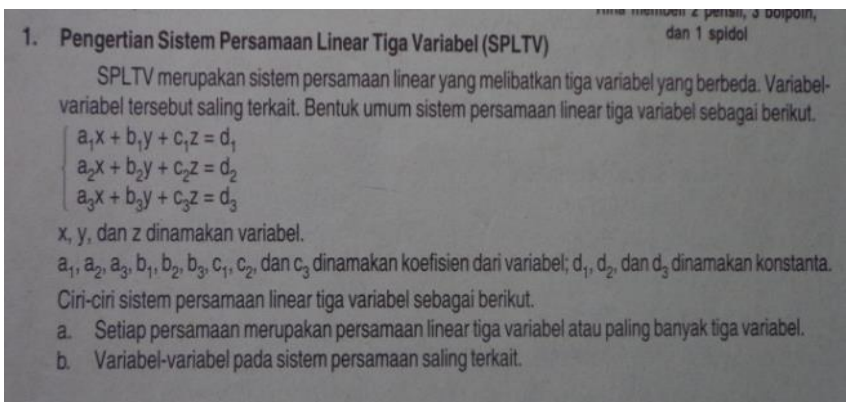

Figure 3. Example of Student Worksheet Presentation Used by Learners

Besides the presentation of the material, other problems that are found are the questions given in student worksheet. The solution given in the sample problem caused the students confusion because of the lack of clear instructions in the completion and the lack of explanation of why the problem was solved in this way. The problems in student worksheet mostly contain multiple choice questions rather than questions and descriptions. This makes the learner often guess the answer of multiple choice given. Student worksheet should be able to maximize the understanding in the effort to form basic skills in accordance with indicators of achievement of learning outcomes that must be pursued.
Based on the description of the problems that have been raised, then a research was conducted to produce mathematics learning devices based on M-APOS model that meets the valid criteria. The indicator of creative thinking used is (1) flexibility, (2) originality, (3) elaboration and (4) fluency.

The formulation of the problem in this study is "how are the characteristics of learning tools in the form of lesson plan and student worksheet based on the M-APOS model that can meet the valid criteria, practice and effective to improve the creative thinking ability of $\mathrm{X}$ class high school students?". The purpose of this study is to know the characteristics of learning tools in the form of lesson plan and student worksheet based on M-APOS model that meets the valid criteria, practice and effective to improve the creative thinking ability of X class high school students.

\section{METHODS}

This type of research is a developmental study using the models of Plomp, starting from the preliminary research phase, the prototyping stage, and the assessment phase. To obtain a valid M-APOS model based learning device, a preliminary research was conducted. Based on the results of the analysis in the preliminary research phase, learning devices based on M-APOS model has been designed. The preliminary research phase consists of needs analysis, curriculum analysis, learner analysis and concept analysis. In the development or prototype phase, learning device based on M-APOS model was designed. The M-APOS modelbased learning tool that has been designed was self-evaluated and validated by experts review. Validation of the device was done by three lecturers of Mathematics, one lecturer of Education Technology and one lecturer of Bahasa Indonesia.

\section{RESULTS AND DISCUSSION}

\section{Preliminary Research Results}

At this stage, identification or analysis is required for the development of M-APOS-based learning devices. Activities in the preliminary analysis begin with needs analysis, curriculum analysis, learner analysis and concept analysis. The description of the results of the initial investigative phase are:

\section{a. Needs Analysis}

In the requirement analysis phase, information gathering about the problems in mathematics learning was conducted. Information gathering was done by interviewing teachers and students and giving questionnaires to learners. Activities undertaken also observed the learning process and learning tools that exist in the field.

The result obtained from the requirement analysis is that the mathematics learning device has not yet been optimally used. The results of interviews with teachers of 
mathematics, it was found that teachers have already implemented various methods in the process of learning mathematics but has not run optimally. Lessons Plan used by teachers has not facilitated learners in improving their ability, especially the ability to think creatively. Working Students Worksheet used by learners is a student worksheet sold by publishers whose contents are more likely to directly present the concept and principle without any process to obtain, so that learners are not accustomed to using the thinking skills in solving the problems given. In addition, student worksheet should also contain commands or questions that guide students to find their own mathematical principles / procedures to stay long-termed and also contains questions that enable students to practice what they have found so as to motivate students to participate active in learning and facilitate students to construct knowledge independently by commanding or answering the questions that exist so that learning is more meaningful.

Therefore schools need a Mathematics Lesson Equipment Based On M-APOS Model to Improve student's Creative Thinking Skill.

\section{b. Curriculum Analysis}

At this stage, the study of Curriculum 2013 for compulsory mathematics subjects of grade X SMA / MA semester I was conducted. This analysis is needed to study the material coverage and learning objectives for each student worksheet meeting. Aspects that are considered in analyzing the curriculum are aspects of Core Competence (KI), Basic Competence (KD). The results of KI and KD analysis are elaborated into indicators of achievement of competencies in order to be easily understood by learners.

\section{c. Analysis of Learners}

Analysis of these learners aims to determine the quality of individuals who can be used as guidance in the design of student worksheet. Student analysis includes academic ability, age, penchant and maturity level, motivation to subject, experience, psychomotor skill, ability of cooperation and activities usually done by learners in their daily life. The analysis was done on the students of class $\mathrm{X}$ SMAN 2 Payakumbuh and SMA 3 Payakumbuh by spreading the questionnaire to learners and observing the learning activities.

The result of analysis of learners were they have a high curiosity, prefer learning activities in groups, easily forget the concept that has been studied previously, and when they told tu record lessons learned some learners don't take note but draw a cartoon. The students are more dominant in favor of student worksheet that are red maroon, blue, and green with paper liked their student worksheet before. They also like to make a conclusion of learned in a box by colored pen's.

\section{d. Analysis of Concept}

Conceptual analysis aims to determine the content and subject matter needed in the development of student worksheet, by identifying the key concepts taught, detailing and arranging them systematically according to the order of presentation. The results of concept analysis based on the curriculum of 2013 on compulsory mathematics of class X SMA semester I, there are 6 chapters which are studied: (1) equations and inequality of absolute value of one variable, (2) rational and irrational inequality of one variable, (3) system of linear equations three variables, (4) the inequality system of two variables (linear-squares and squares), (5) functions.

2. Design Prototype

a. Designing Mathematic Lesson Equipment

Designing M-APOS based math lesson equipment based on analysis in the preliminary research. The result of this design will produce prototype 1. Math lesson equipment is designed by referring to the learning characteristics based on M-APOS model. The description of the design of learning tools based on M-APOS models are as follow

\section{1) Designing Lesson Plan}

The lesson plan is systematically designed containing the components of lesson plan writing contained in permendikbud no 022 of 2016, that is about process standards for primary and secondary education concerning lesson plan components. In preparing lesson plan there are several principles that need to be considered that learning process is designed as attractive as possible with the centered on students so as to encourage motivation, interest, creativity, initiative, inspiration, independence and spirit of learning. Lesson plan is designed to develop a reading passion, understanding of reading and expression in various forms of writing, providing feedback and follow-up the students. Lesson plan is prepared by considering the linkage and integration between $\mathrm{KI}, \mathrm{KD}$, learning materials, learning activities, indicators of competency achievement, assessment, and learning resources in a whole learning experiences.

The main activities of lesson plan are based on MAPOS model-based learnings syntax. Learning begins with the action phase. At this stage students are given a problem related to the concept to be learned, students are asked to identify the problems. Furthermore, students are given procedural steps to solve the problems in the form of giving clear instructions on student worksheet. The second phase is the process phase. At this stage students are given a second problem, then students are asked to solve the problem by repeating the completion steps that have been given in the action phase. Furthermore, students are asked to apply the ideas or mathematical concepts that have been obtained so that students are able to provide reasons or explanations about is properties. This phase is called the phase object. Further activities of the students are asked to link all of their understanding so that the phase of action, process and object are connected to ech other. This phase is called the schema phase. Student's achievement is set in this phase, that is 
when students have the ability to construct examples of a mathematical concept according to the nature of the concept. Then students do class discussions activities. One group will show the result of their group discussion activities. One group will show the results of their group discussion in front of the class and other group will add information to the group. Further students do the exercises on the problems which is in student worksheet.

\section{2) Designing Student Worksheet}

Student Worksheet based on the M-APOS model has several components namely title, KI, KD, indicator, learning objectives, student worksheet instructions, problems, work steps, and exercises. Student worksheet has interesting picture in accordance with the given problem. Student worksheet is designed with bright and variety of colors with red maroon as the dominant color. Student worksheet begins by providing problems aimed at helping students to relate the observed phenomena to the concepts to be constructed. Furthermore, to train the creative thinking ability of students, the problems that close to everyday life are given in order to students can understand well. The questions given are various. It aims to trigger students to solve it in their own way, clearly describe it and be able to solve it by not just one way but able to develop it with the settlement with other methods. Student worksheet uses a simple and communicative language and in accordance with the communication level of students, so that the presentation of the material on student worksheet can be well understand. The questions in student worksheet are arranged with clear sentences so as to lead students to get the expected answers.

Learning activities in student worksheet begins with action phase. In the action phase students are given a problem and students are given procedural steps to complete it. These steps will guide students to determine the resolution of the problem given.

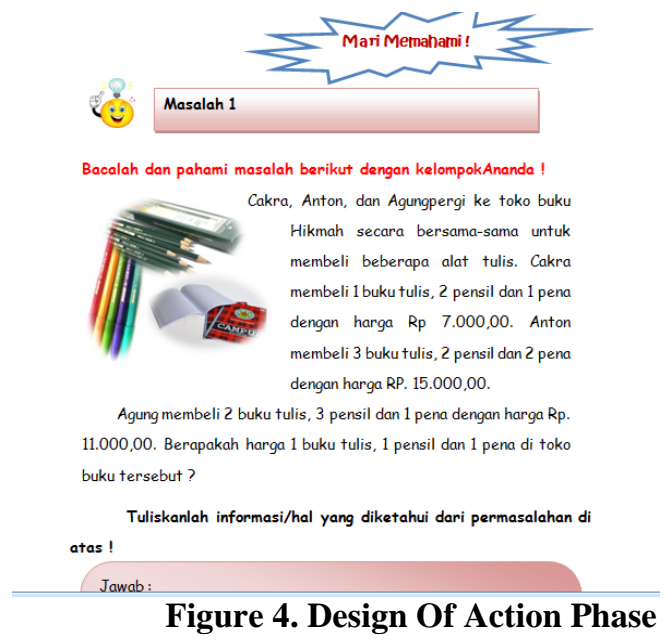

Furthermore, students are given a second problem. The problem will be solved by students in the same way as solving problems in the action phase.

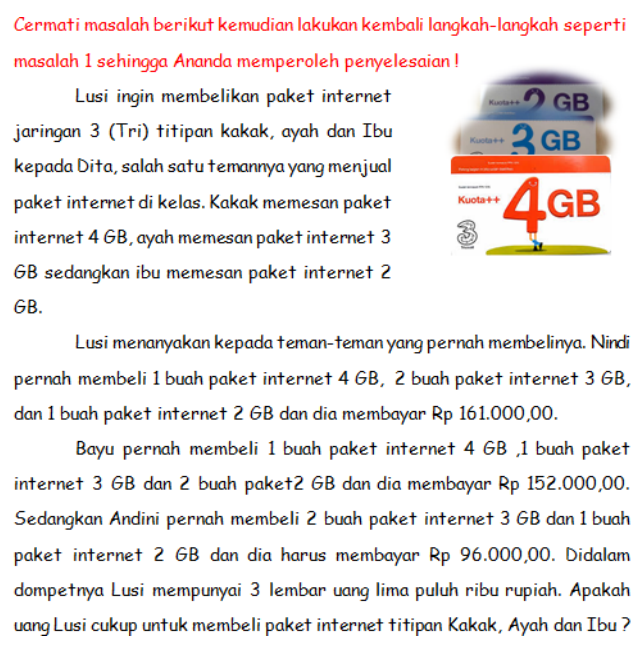

\section{Figure 5. Design Of Process Phase}

Furthermore, students are asked to apply the ideas or mathematical concepts that have been obtained so that students are able to provide reasons or explanations about is properties. This phase is called the phase object.

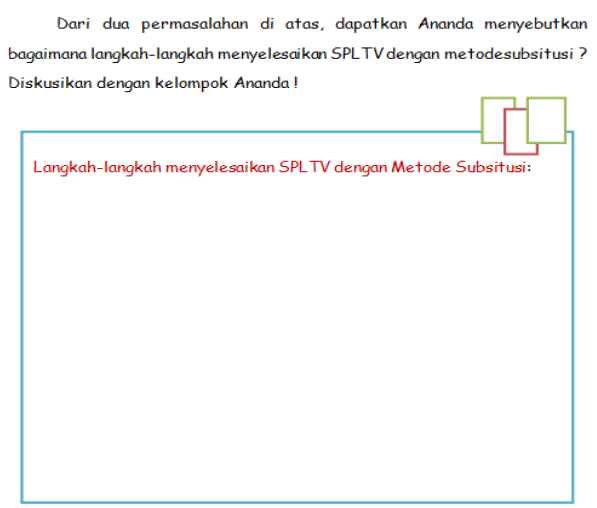

Figure 6. Design Of Object Phase

Further activities of the students are asked to link all of their understanding so that the phase of action, process and object are connected to each other. This phase is called the schema phase.

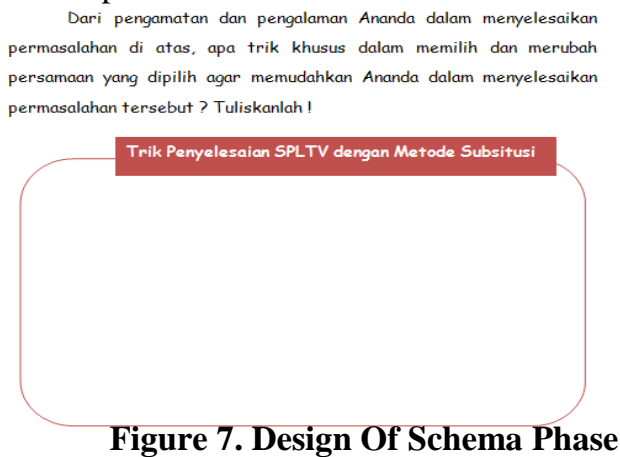

After that, student do class discussion. One of groups presents the result of their discussion and other group listens, responds and add informations obtained in the group. And then, the teacher ask students to complete the exercise to. The purpose of it is to see how far the students understanding of the materials have been learned. 


\section{b. Prototype 1}

The result of the design of lesson equipment in the early stages are called Prototype 1. Lesson equipment are further validated, to obtain a valid devices by previously doing self evaluation. Next step is discusses the learning tools with 3 experts. Below is outlined the validation result of prototype learning devices that have been designed.

[1] Self evaluation

The first activity undertaken after designing the lesson equipment is self-examined by the researcher. Before consulting and discussing to the experts, self-evaluation to the learning device that has been designed is done first. In general, many errors occur in typing errors, unclear sentences and punctuation errors. For example in the lesson plan, there is typing error word "perbedaan" that should be "perbedaan". There are also errors in the use of punctuation such as point punctuation. In some sentences do not use punctuation. After the self evaluation of the learning device based on M-APOS model that has been designed, then the improvements are the consulted and discussed with experts.

[2] The results of validation of learning tools by expert

Lesson equipment validated by 5 validators which consists of 3 lecturer of mathematicians, 1 lecturer of educational technology and 1 lecturer of Indonesian language. In the lesson plan, the aspect which observed are lesson plan components and its formats, identity of the lesson plan, $\mathrm{KI}$ and $\mathrm{KD}$, formulation of learning steps, selection of learning resources, assessment, language and writing and lesson plan benefits.

There are several revisions suggested by the validator during the validation process. Based on the validator's suggestion, there are several things that need to be improved, in the M-APOS model has not been seen yet, there is no answers to the problems given to student worksheet, and there is no activity to discuss the homework which was given at the previous meeting. After the lesson plan is revised based on the validator's suggestion, then the validator provides an assessment. The average validation result for lesson plan is 0,790 with valid criteria. Thus it can be concluded that the component aspect of lesson plan based on M-APOS model is valid.

In student worksheet, the aspects which are observed are aspects of didactic or presentation, material and content aspects, linguistic aspects, and aspects of graphics or appearance. During the validation process there are several revisions suggested by the validators. After the revisons are made, the validators provide an assessment of student worksheet. Student worksheet validation on aspects didactic or presentation and material aspects and content is done by 3 lecturers of mathematics. The average validation result in student worksheet for didactic is 0,744 which is in valid criteria, content aspect is 0,778 with the valid criteria, content aspect is 0,778 with the valid criteria, language aspect is 0,867 with valid criteria and aspect of graphics is
0,667 with the valid criteria so that average for all four aspect is 0,764 with valid criteria. Thus it can be conclude that student worksheet has valid from aspect didactic, aspect of content/material, aspect of language and aspect of graphics/appearance

\section{c. Prototype 2}

The activities carried out on prototype 2 are testing the practicalities of the learning tools. Practicality test aims to know the extent to which given problems can be understood, the use of elusive terms, the questions and command phrases which are difficult to understand. Evaluation is done by asking students to comment on student worksheet that has been designed. Student worksheet is given to students of class X MIA 3 who have high, medium, and low ability of 1 person each. Students are asked to read and do student worksheet. The evaluation of one-to-one is done in 6 meetings. During the one to one process, there are several revisions including some questions, command phrases and problems that are difficult to understand by students. For that reason, a revision of student worksheet is made. After the student worksheet revision process is completed, an improvement of prototype 2 is done according to the student's suggestion. The revisions result on prototype 2 is called prototype 3 .

\section{d. Prototype 3}

The activities undertake on prototype 3 are testing the learning tool's practicality by means of small group evaluation. Small group evaluation is done by practicing learning tool that has been designed on a group of students consisting of 6 people. The revision of prototype 3 is called prototype 4. This small group evaluation is conducted on high-achieving, medium and low students of X grade of MIA 3 in 6 meetings. Based on the observation of the student's activities during the small group, it is concluded that the students are enthusiastic and interested in doing student worksheet, the time spent to do is enough although at the first meeting is not enough. Likewise in terms of presentation of student worksheet. Student worksheet is interesting with the problems in everyday life, although initially students feel difficult because rarely solve the questions but students look enthusiastic to try it. In the part of learning strategy by using the problems related to daily life is quite interesting, the questions help students solve problems and make conclusions. activities at student worksheet are interesting, the presentation of drawings and illustrations on student worksheet makes it easy for them to understand the concept of the material they are learning.

\section{e. Prototype 4}

Results from revisions to individual and small group evaluations followed by field testing (prototype 4) in X grade of MIA 1. Testing of M-APOS model based learning devices in larges classes was conducted in 6 meetings. During a large class trial, researchers were assisted by one teacher and one observer. Teacher teach with tools that 
designer have designed. Observer in charge of observing the implementation of learning with the M-APOS model based advocacy tool using a questionnaire of observation of the implementation.

Practicality data of M-APOS model based learning device is obtained from questionnaire of teacher and student, also from the observation of learning implementation. The effectiveness of instructional tools is seen from the results of creative thinking ability of students problems.

In the first meeting, the student has not been accustomed to learning with the M-APOS model. Students are still hesitant and ask how to solve problems in student worksheet. But students are very interested to learn using student worksheet given. At the second meeting, the students began accustomed to implement learning with the model of M-APOS. Although many students still ask some questions. The development of creative thinking ability of students at the second meeting has started to have an increase. The third meeting until the last meeting that is sixth meeting, the development of creative thinking ability of students is in accordance with the expected indicators and increased every meeting. These indicators are flexibility, originality, elaboration, and fluency. Lesson plan practicality questionnaires are also given to teachers of mathematics grade X SMA N 3 Payakumbuh after the learning is done. Based on the questionaire analysis, the teacher response to lesson plan is in the range of $75 \%$ to $100 \%$ for practical and very practical category. Generally, the average of teacher's response questionnaire to learning device based on M-APOS model is $84,89 \%$ with practical category.

The effectiveness of mathematics learning tool is seen form the test result of creative thinking ability of students after learning by using M-APOS based mathematic learning tool. Prior to the field test class, final test questions were tested in different classes to see validity, distinguishing power, difficulty and reliability index. The test of final test is done in grade X MIA 4. After final test is tested in different class, final test is done in field test class. The effectiveness of learning devices based on M-APOS model is also seen from the acquisition of test scores of creative thinking ability of students.

\section{TABLE 1. PERCENTAGE OF TEST FOR THE CREATIVE}

THINKING ABILITY OF THE STUDENTS

\begin{tabular}{|c|c|}
\hline $\begin{array}{c}\text { Indicator of Creative Thinking } \\
\text { Ability }\end{array}$ & $\begin{array}{c}\text { Percentage of Scores For Each } \\
\text { Indicator }(\%)\end{array}$ \\
\hline Flexibility & 78,68 \\
\hline Origanality & 58,09 \\
\hline Elaboration & 89,71 \\
\hline Fluency & 87,50 \\
\hline Average & 78,49 \\
\hline
\end{tabular}

Based on the results of the test of creative thinking ability above, it is obtained an average percentage of $78,49 \%$ with the creative category. Then it can be concluded that the learning tool based on M-APOS model is effective to improve student's creative thinking ability.

\section{CONCLUSIONS AND SUGGESTIONS}

Based on the research that has been implemented then obtained the following conclusions:

1. The learning tools has met the valid criteria based on the validation result by the experts.

2. M-APOS model based learning tool has met the practical criteria with the characteristic of the ease of use of lesson plan and student worksheet.

3. M-APOS model based learning tools has a positive impact on the improvement of creative thinking ability because learning using M-APOS model based learning tool has facilitated the students to think creatively. Logically, and systematically.

It is suggested to teachers and students to keep using this student worksheet in order to help the creative thinking ability of students as well as support from the school to facilitate the use of lesson plan and student worksheet required by teachers and students.

\section{REFERENCES}

[1] Arnawa. M, Meningkatkan Kemampuan Pembuktian Mahasiswa dalam Aljabar Abstrak Melalui Pembelajaran Berdasarkan Teori APOS, Disertasi pada Universitas Pendidikan Indonesia: tidak diterbitkan, 2006

[2] Asiala. M et al, "A Framework for Research and Curriculum Development In Undergraduate Mathematics Education". Journal of Mathematical Behavior, (online), 1997. (http://www.math.wisc.edu/ wilson/Courses/Math903/APOSOverview.pdf)

[3] Asiala. M et al, "The Development of Students' Graphical Understanding of The Derivative", (online), (http://www.math.kent.edu/ edd/SlopeStudy.pdf), 2001.

[4] Csikszentmihalyi. M, Creativity, Flow and the Psychology of Discovery and Invention, New York: HarperCollins Publ. Inc, 1996.

[5] Dubinsky. E., M. McDonald, APOS: A Constructivist Theory of Learning, In Undergraduates Mathematics Education Research, In Holton, D. (Eds), "The Teaching and Learning of Mathematics at University Level", Kluwer Academic Publisher, Dordreeth, 2000. (https://pdfs.semanticscholar.org/6850/b01648bf43e15cbdbcf871b21 5c3cf44825d.pdf).

[6] Maharaj. Aneshkumar, "An APOS Analysis of Natural Science Students' Understanding Of Derivatives”, 33 (1): 3-5, 2013.

[7] Nurina. Happy., Djamilah. Bondan. Widjajanti, "Keefektifan PBL Ditinjau dari Kemampuan Berfikir Kritis dan Kreatif Matematis, Serta SELF-ESTEEM Siswa SMP", 1 (1): 10-12, 2014.

[8] Nurlaelah. E, "Kajian Hasil-Hasil Penelitian Yang Berkaitan dengan Teori APOS dan Kreatifitas Matematika. Universitas Pendidikan Indonesia": tidak diterbitkan. Diambil 20 Januari 2017 (http://file.upi.edu/Direktori/FPMIPA/JUR_PEND_MATEMATIKA/ 196411231991032-ELAH NURLAELAH/MK.Elah 22.pdf), 2009.

[9] Plomp. T., N. Nieveen, Educational Design Research. Enschede: Netherland Institute for Curriculum Development (SLO), 2013.

[10] Shadiq. Fadjar, Pembelajaran Matematika : Cara Meningkatkan Kemampuan Berfikir Siswa. Yogyakarta: Graha Ilmu, 2014.

[11] Suryadi. D, Membangun Budaya Baru dalam Berfikir Matematika, Bandung: Jica, 2010.

[12] Trianto. Mendesain Model Pembelajaran Inovatif-Progresif, Surabaya: Kencana Prenada Media Group, 2009.

[13] Yerizon, Meningkatkan Kemampuan Pembuktian Matematis Melalui Pendekatan Modifikasi APOS Pada Mahasiswa, Disertasi pada Universitas Pendidikan Indonesia: tidak diterbitkan. 2011. 